\title{
Induction of ovulation and superovulation in mares using equine LH and FSH separated by hydrophobic interaction chromatography
}

\author{
S. Hofferer, F. Lecompte, T. Magallon, E. Palmer and \\ Y. Combarnous
}

INRA Station de Physiologie de la Reproduction des Mammifères Domestiques (PRMD), CNRS Unit

1291 F-37380 Nouzilly, France

\begin{abstract}
Pharmacological control of reproduction in mares requires the use of equine gonadotrophins to avoid induced immunological resistance. Crude equine gonadotrophins (CEG) have been used but the presence of equine luteinizing hormone $(\mathrm{eLH})$ and follicle-stimulating hormone $(\mathrm{eFSH})$ in $\mathrm{CEG}$ has led to disappointing results in superovulation studies. Separation of eLH and $\mathrm{eFSH}$ activities from CEG is necessary to overcome this problem. The hydrophobic properties of the two hormones were sufficiently different to permit their separation by hydrophobic interaction chromatography (HIC) on a phenyl Sepharose matrix. Good yields of separate FSH and LH fractions were readily obtained by stepwise elution and the method was adapted for large scale preparations of enriched fractions of eLH and eFSH. Two experiments were performed in vivo to evaluate the biological activity of the HIC fractions. Experiment 1 showed that biological activity of the LH fraction in inducing ovulation of preovulatory follicles was similar to that obtained with CEG, indicating that LH bioactivity was not altered by HIC. Experiment 2 demonstrated that biological activity of the FSH fraction was identical (as far as rate of ovulation was concerned) to that of CEG in superovulating mares, indicating that FSH activity was also not altered by HIC. Although we have not obtained better results with the separate equine gonadotrophins than with CEG, it is potentially advantageous to use preparations with single activity to obtain a controlled balance of FSH and LH activity. The HIC technique was chosen because it could easily be scaled up to provide the large amounts of the separate hormones needed for the treatment of a large number of mares.
\end{abstract}

\section{Introduction}

In equine species, the pharmacological control of reproduction requires the use of equine gonadotrophins: injections of heterologous hormone preparations lead to strong immune responses and, therefore, repeated treatments are inefficient (Roser et al., 1979; Bour, 1984).

Until now, crude equine gonadotrophin (CEG) preparations from pituitaries containing both equine follicle-stimulating hormone $(\mathrm{eFSH})$ and luteinizing hormone $(\mathrm{eLH})$ have been used to induce the growth of multiple follicles in cyclic or anoestrous mares (Lapin and Ginther, 1977; Woods and Ginther, 1983) or to induce ovulation (Duchamp et al., 1987). Usually, large amounts of eLH are contained in CEG, but concentrations of eFSH in extractions are variable. This could be a reason for disappointing results obtained in superovulation studies (e.g. low ovulation rate and limited fertility).

In other species better results of superovulation have been obtained by using FSH and LH separately so that the exact amount of each hormone and the sequence of injections can be controlled (Chupin et al., 1984). Separation of eLH and eFSH

Revised manuscript received 26 November 1992. activities from CEG was therefore necessary and the selected method should allow the preparation of large amounts of each gonadotrophin for treatments in vivo.

Equine LH and FSH activities cannot be separated by fractionated precipitation or gel filtration. Moreover, as the isoelectric points of the eLH and eFSH isoforms fall in the same range, they must be individually purified to avoid crosscontamination. Indeed, we have previously used successive ion exchange chromatography to obtain highly purified preparations of eFSH (Combarnous and Hengé, 1981) and eLH (Guillou and Combarnous, 1983), but this method does not permit one-step separation of the two activities with high yields. We therefore used hydrophobic interaction chromatography (HIC) on analytical and preparative scales.

\section{Materials and Methods}

Preparation of eFSH and eLH fractions

Standards, hormones and antibodies. Hormonal activities were measured with two standards prepared in our laboratory: eLH CY760 equivalent to $11.4 \times \mathrm{NIH} \mathrm{LH} \mathrm{S2}$ and eFSH 


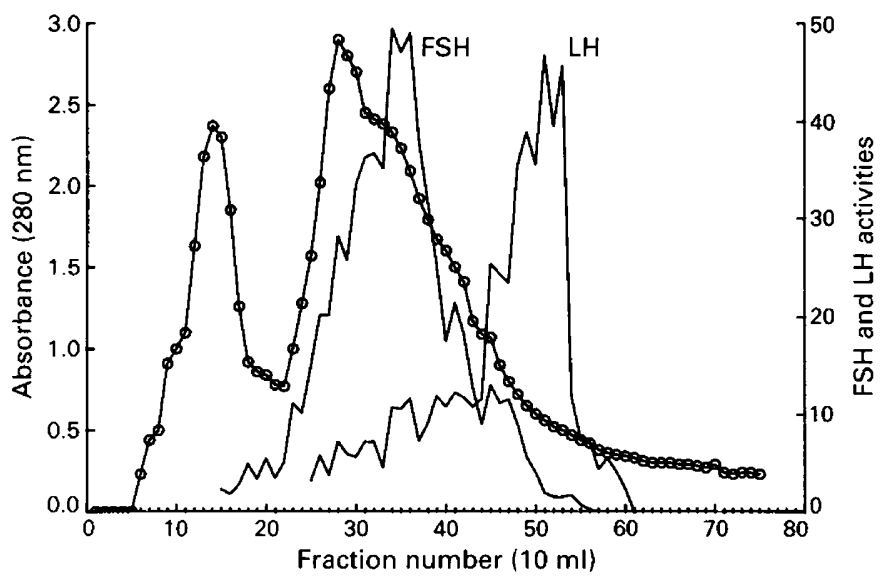

Fig. 1. Gradient hydrophobic interaction chromatography of equine pituitary extract: absorbance profile at $280 \mathrm{~nm}(\mathrm{O})$ and distribution of FSH and LH immunoactivities are shown. The sample, $1 \mathrm{~g}$ crude equine gonadotrophins (CEG), was applied to a phenyl Sepharose CL4B column $(2.5 \mathrm{~cm} \times 12 \mathrm{~cm})$ equilibrated in $0.05 \mathrm{~mol}$ ammonium bicarbonate $\mathrm{I}^{-1}$ and eluted with a linear gradient of $1.0-0 \mathrm{~mol}$ ammonium sulfate $1^{-1}$ together with $0-50 \%$ ethylene glycol in $0.05 \mathrm{~mol}$ ammonium bicarbonate $\mathrm{l}^{-1}$ from fractions 15 to 60 .

CY1368 equivalent to $1016 \times \mathrm{NIH}$ FSH S1, as estimated in homologous radioreceptor assays (Guillou and Combarnous, 1983).

The antibodies used in the enzyme-linked immunosorbent assays (ELISA) were a rabbit anti-eFSH (803) antiserum characterized by Combarnous and Hengé (1981) for eFSH ELISA and a rabbit anti-PMSG serum characterized by Cahoreau and Combarnous (1987) for eLH ELISA.

Three batches of crude equine gonadotrophins (CEG-EX6, CEG-EX7 and CEG-EX9) were prepared as described by Guillou and Combarnous (1983). The LH-specific activities were 0.280 , 0.120 and $0.080 \times$ eLH CY760 for EX6, EX7 and EX9, respectively. The FSH activities were $0.076,0.035$ and $0.050 \times \mathrm{eFSH}$ CY1368 for EX6, EX7 and EX9, respectively. The FSH:LH activity ratios are thus similar for EX6 (0.27) and EX7 (0.29) but significantly higher for EX9 (0.62).

Assays. The FSH immunological activities of the fractions were measured in an ELISA. Plastic 96-well microtitre plates (CML, Angers) were coated with purified eFSH CY1368 (100 $\mu \mathrm{l}$ per well; $250 \mathrm{ng} \mathrm{ml}^{-1}$ in $0.1 \mathrm{~mol}$ carbonate bicarbonate buffer $\mathrm{I}^{-1}, \mathrm{pH} 9.6 ; 37^{\circ} \mathrm{C}$ for $\mathrm{I} \mathrm{h}$ ). Just before use, the wells were saturated with BSA $\left(200 \mu \mathrm{l}, 2 \mathrm{mg} \mathrm{m}{ }^{-1}, 37^{\circ} \mathrm{C}\right.$ for $\left.\mathrm{I} \mathrm{h}\right)$ and washed with PBS-Tween buffer. In parallel, the samples (200 $\mu \mathrm{l}$ of standard or unknown diluted in PBS-Tween buffer, $\mathrm{pH}$ 7.6) were incubated with $200 \mu \mathrm{l}$ antiserum (1:10 000 dilution) for $1 \mathrm{~h}$ at $37^{\circ} \mathrm{C}$ in plastic $3 \mathrm{ml}$ test tubes. Three $100 \mu \mathrm{l}$ aliquots of this mixture were then transferred to the eFSH-coated wells and incubated for $\mathrm{I} \mathrm{h}$ at $37^{\circ} \mathrm{C}$ to allow specific binding of the antibody molecules not already occupied by hormone. After three washes of the well with PBS-Tween buffer, bound antibody was detected with an ovine anti-rabbit IgG antibody conjugated to peroxidase (100 $\mu \mathrm{l}$ per well, 1:400 dilution) purchased from Pasteur Production (Paris). The substrate was ortho-phenyl diamine $(0.05 \mathrm{mg}$ in $100 \mu \mathrm{l})$ in $\mathrm{H}_{2} \mathrm{O}_{2}$.
The LH immunological activities of the fractions were measured in an ELISA for eCG/PMSG (Lecompte and Combarnous, 1992); eLH and eCG have some identical amino acid sequences (Bousfield et al., 1987) and eLH consequently crossreacts very strongly in the eCG immunoassay. On a weight basis, eLH activity in the ELISA ranged from 0.45 to 0.6 times the activity of eCG. The experimental procedure was identical to that used for eFSH. Briefly, PMSG (100 $\mu \mathrm{l}$, 2.5 iu $\mathrm{ml}^{-1}$ : Searle, Angers) is coated onto 96-well microtitre plates, and the concentration of eLH measured by its inhibition of the binding of the anti-PMSG antibody (1:30 000 dilution) to coated PMSG. As above, bound antibody was detected with ovine anti-rabbit IgG antibody conjugated to peroxidase.

The crossreactivity of eFSH in the eLH assay was $3 \%$ and the crossreactivity of eLH in the eFSH assay was $1 \%$. For both assays, sensitivity (amount of hormone corresponding to $\mathrm{B}: \mathrm{B}_{0}=90 \%$ ) was $40 \mathrm{ng} \mathrm{ml}^{-1}$. The intra-assay coefficient of variation was $10 \%$ and the interassay coefficient of variation was $15 \%$.

Gradient hydrophobic interaction chromatography. A $60 \mathrm{ml}$ $(2.5 \mathrm{~cm} \times 12 \mathrm{~cm}$ ) column of phenyl Sepharose CL4B (Pharmacia, Uppsala) was equilibrated with 1 mol ammonium sulfate $\mathrm{l}^{-1}$ in $0.05 \mathrm{~mol}$ ammonium bicarbonate $1^{-1}$ at room temperature. Crude pituitary extract ( $1 \mathrm{~g}$ of EX6) dissolved in $50 \mathrm{ml}$ of $1 \mathrm{~mol}$ ammonium sulfate $\mathrm{l}^{-1}$ in $0.05 \mathrm{~mol}$ ammonium bicarbonate $\mathrm{l}^{-1}$ was applied to the column and eluted at $100 \mathrm{ml} \mathrm{h}^{-1}$. Optical density at $280 \mathrm{~nm}$ and ionic strength of the eluate were recorded throughout the chromatography.

After loading of the sample, a decreasing linear gradient of ammonium sulfate $\left(1-0 \mathrm{~mol} \mathrm{l}^{-1}\right)$ was applied together with an increasing gradient $(0-25 \%)$ of ethylene glycol in $0.05 \mathrm{~mol}$ ammonium bicarbonate $\mathrm{l}^{-1}$. Fractions of $10 \mathrm{ml}$ were recovered and assayed for LH and FSH activities in the immunoassays described above. The eluate was pooled in five fractions; fraction I (6-22), II (23-30), III (31-44), IV (45-54) and V (55-70) which were then dialysed, freeze dried and assayed.

Stepwise hydrophobic interaction chromatography. A phenyl Sepharose CL4B column $(2.5 \mathrm{ml})$ equilibrated in $1 \mathrm{~mol}$ ammonium sulfate $\mathbf{l}^{-1}$ at room temperature was loaded with crude pituitary extract $(80 \mathrm{mg}$ EX7) dissolved in $1 \mathrm{ml} 1 \mathrm{~mol}$ ammonium sulfate $\mathrm{l}^{-1}$ at $25 \mathrm{ml} \mathrm{h}^{-1}$. Buffer changes were made after total elution of each protein peak.

The first non-retained protein peak was collected in $20 \mathrm{ml}$ of 1 mol ammonium sulfate $\mathrm{l}^{-1}$ eluate (fraction I). The buffer was changed to $0.05 \mathrm{~mol}$ ammonium bicarbonate $\mathrm{l}^{-1}$ and a second protein peak was eluted in $18 \mathrm{ml}$ eluate (fraction II). The third buffer was $50 \%$ ethylene glycol in $0.05 \mathrm{~mol}$ ammonium bicarbonate $\mathrm{I}^{-1}$ and the third protein peak was eluted in $15 \mathrm{ml}$ eluate (fraction III). The three fractions were then desalted on an $80 \mathrm{ml}$ exclusion column of AcA 202 (Industrie Biologique Française: IBF) in $0.05 \mathrm{~mol}$ ammonium bicarbonate $1^{-1}$. Fraction I was recovered in $31 \mathrm{ml}$ eluate, fraction II in $31 \mathrm{ml}$ and fraction III in $24 \mathrm{ml}$. Each fraction was frozen, freeze dried and assayed.

For the large scale preparation, a $160 \mathrm{ml}(4.5 \times 10 \mathrm{~cm})$ phenyl Sepharose column equilibrated with $1 \mathrm{~mol}$ ammonium sulfate $\mathrm{l}^{-1}$ was loaded with crude extract $(2.5 \mathrm{~g}$ EX9) dissolved in $70 \mathrm{ml}$ of $1 \mathrm{~mol}$ ammonium sulfate $\mathrm{I}^{-1}$. The first fraction of non-retained protein (fraction I) was recovered in $300 \mathrm{ml}$ eluate. 
Table 1. Recovery and activity of LH and FSH in gradient hydrophobic chromatography fractions

\begin{tabular}{|c|c|c|c|c|c|c|}
\hline \multirow[b]{2}{*}{ Fraction } & \multirow{2}{*}{$\begin{array}{l}\text { Weight } \\
\text { (mg) }\end{array}$} & \multicolumn{2}{|c|}{ LH activity* } & \multicolumn{2}{|c|}{ FSH activity $\dagger$} & \multirow[b]{2}{*}{ FSH:LH } \\
\hline & & Specific & Total & Specific & Total & \\
\hline $\begin{array}{l}\text { Crude equine } \\
\text { gonadotrophins CEG-EX6 }{ }^{\mathrm{a}}\end{array}$ & 1000 & 0.28 & 280 & 0.076 & 76 & 0.27 \\
\hline$I(6-22)$ & 147 & 0 & 0 & 0.005 & 0.7 & \\
\hline II $(23-30)$ & 292 & 0 & 0 & 0.05 & 7.4 & \\
\hline III $(31-44)$ & 294 & 0.20 & 58.8 & 0.15 & 44.1 & 0.75 \\
\hline IV $(45-54)$ & 77 & 0.69 & 53.1 & 0.03 & 2.3 & 0.04 \\
\hline$V(55-70)$ & 60 & 0.15 & 9.0 & 0.01 & 0.6 & 0.07 \\
\hline Total & $\begin{array}{c}870 \\
(87 \%)\end{array}$ & & $\begin{array}{l}120.9 \\
(43 \%)\end{array}$ & & $\begin{array}{l}55.1 \\
(73 \%)\end{array}$ & \\
\hline $\begin{array}{l}\text { Crude equine } \\
\text { gonadotrophins CEG-EX } 7^{\mathrm{b}}\end{array}$ & 80 & 0.12 & 9.6 & 0.035 & 2.8 & 0.29 \\
\hline I & 13.5 & 0 & 0 & 0 & 0 & \\
\hline II & 36 & 0.016 & 0.58 & 0.07 & 2.52 & 4.34 \\
\hline III & 9.4 & 0.7 & 6.58 & 0 & 0 & 0 \\
\hline Total & $\begin{array}{r}58.9 \\
(74 \%)\end{array}$ & & $\begin{array}{r}7.16 \\
(75 \%)\end{array}$ & & $\begin{array}{r}2.52 \\
(90 \%)\end{array}$ & \\
\hline $\begin{array}{l}\text { Crude equine } \\
\text { gonadotrophins CEG-EX9 }\end{array}$ & 2500 & 0.08 & 200 & 0.056 & 140 & 0.7 \\
\hline I & 280 & 0.002 & 0.6 & 0.003 & 0.8 & 1.3 \\
\hline II & 1060 & 0.03 & 31.8 & 0.125 & 132.5 & 4.2 \\
\hline III & 450 & 0.25 & 112.5 & 0.016 & 7.2 & 0.06 \\
\hline Total & $\begin{array}{l}1760 \\
(72 \%)\end{array}$ & & $\begin{array}{l}144.9 \\
(72 \%)\end{array}$ & & $\begin{array}{l}140.5 \\
(100 \%)\end{array}$ & \\
\hline
\end{tabular}

${ }^{*} \mathrm{LH}$ immunoactivity in terms of eLH CY760.

†FSH immunoactivity in terms of eFSH CY1368.

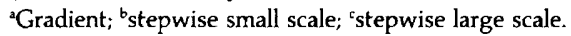

Fraction II was recovered in $400 \mathrm{ml}$ and fraction III in $200 \mathrm{ml}$ eluate. All fractions were desalted on an $800 \mathrm{ml} \mathrm{AcA} 202$ (IBF) exclusion column in $0.05 \mathrm{~mol}$ ammonium bicarbonate $1^{-1}$. This column allowed desalting of up to $160 \mathrm{ml}$ solution. Consequently, each fraction was divided into aliquots to be desalted with high efficiency. Each fraction was then frozen, freeze dried and assayed.

\section{In vivo treatments in mares}

Animals. Selle français mares, 450-550 kg, 4-17 years old (Expt 1) or pony mares, $250-350 \mathrm{~kg}, 3-15$ years old (Expt 2) were used during the breeding season (April, May and June) and all were cyclic. Animals were housed in boxes with free access to a paddock during the day.

Experiment 1. The LH activity in CEG and HIC fraction III was assessed by attempting to induce ovulation in mares by i.v. injection (Duchamp et al., 1987). Induction was performed with CEG-EX9 when a follicle reached a diameter of $35 \mathrm{~mm}$ (assessed by ultrasonography). Ovulation occurred in $75 \%$ of treated animals within $48 \mathrm{~h}$, whereas ovulations of control mares were spread over 6 days.
To evaluate the biological activity of the eLH fraction (fraction III from CEG-EX9) obtained by stepwise HIC, we tested induction of ovulation in three groups of cyclic mares. Mares were examined by ultrasonography (Palmer and Driancourt, 1980) every other day until the largest follicle reached $30 \mathrm{~mm}$ in diameter and then daily. The day on which a $35 \mathrm{~mm}$ follicle was detected, animals were randomly assigned to one of three experimental groups: (1) Control group $(n=25)$ receiving $5 \mathrm{ml}$ physiological saline i.v.; (2) CEG group $(n=25)$ receiving $25 \mathrm{mg}$ CEG-EX9 (equivalent to $2 \mathrm{mg}$ eLH CY760 and $1.25 \mathrm{mg}$ eFSH CY1368) in $5 \mathrm{ml}$ physiological saline i.v.; and (3) $\mathrm{LH}$ group ( $n=28$ ) receiving $8 \mathrm{mg}$ fraction III (equivalent to $2 \mathrm{mg}$ eLH CY 760 and $0.12 \mathrm{mg}$ eFSH CY1368) in $5 \mathrm{ml}$ physiological saline i.v.

Ovulation was detected by daily ultrasonography after treatment. Response to induction of ovulation was tested by comparison of the number of mares ovulating during the $48 \mathrm{~h}$ after injection of saline, eLH or CEG.

Experiment 2. To test the ability of the eFSH-enriched fraction II obtained by HIC to induce the growth of multiple follicles, we compared the ovarian response to superovulation treatment with either CEG-EX9 or HIC fraction II from CEG-EX9 (FSH). Oestrus in 27 pony mares was synchronized with $0.5 \mathrm{mg}$ allyl 

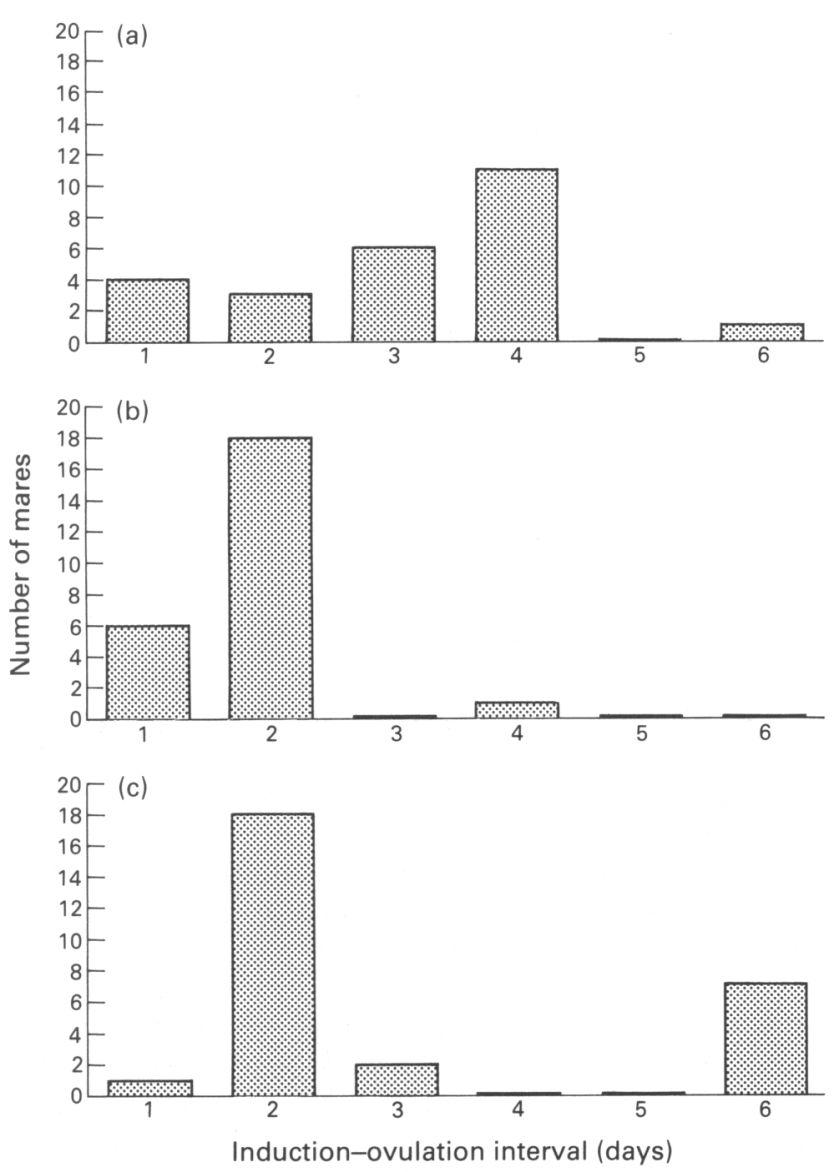

Fig. 2. Evaluation of LH bioactivity of fraction III from hydrophobic interaction chromatography in mares (Expt 1). Results are shown as number of mares ovulating each day after injection of (a) saline, (b) crude equine gonadotrophins and (c) eLH (fraction III). The mares were injected as soon as a follicle $>35 \mathrm{~mm}$ was detected for the first time by ultrasonography.

trembolone (Regumate: Roussel-UCLAF, Paris) in a vaginal sponge for 7 days (Palmer, 1987) followed by an i.m. luteolytic injection of the prostaglandin analogue Estrumate (ICI, Meaux) in $0.5 \mathrm{ml}$ vehicle at sponge removal. They were then randomly assigned to three groups of nine animals. (1) Control group: mares were not treated during follicular growth. On the day that a $34 \mathrm{~mm}$ follicle was detected, ovulation was induced with 25 mg CEG-EX9 i.v. (Duchamp et al., 1987). (2) CEG group: the mares received an i.m. injection of $25 \mathrm{mg}$ CEG-EX9 (equivalent to $1.25 \mathrm{mg}$ eFSH CY $1368+2 \mathrm{mg}$ eLH CY760) every day starting 3 days after prostaglandin injection until at least two follicles reached a diameter of $34 \mathrm{~mm}$. At the end of this treatment, ovulations were induced in the same way as in the control group. (3) FSH group received an i.m. injection of $10 \mathrm{mg} \mathrm{FSH}$ fraction (equivalent to $1.25 \mathrm{mg}$ eFSH CY $1368+0.3 \mathrm{mg}$ eLH CY760) every day following the same procedure as in the CEG group. Treatment took place within 3 days after the end of progestagen treatment to ensure that follicular selection had not yet occurred. Follicular growth was monitored by ultrasonography every other day when the diameter of the largest follicle was under $20 \mathrm{~mm}$ and once a day in other cases. The size of all follicles $>10 \mathrm{~mm}$ was recorded. Luteinized unruptured follicles were characterized by preovulatory size and progressive appearance of echogenic spots.

\section{Results}

\section{Preparation of $F S H$ and $L H$ fractions}

Gradient HIC. Pituitary extracts generally contain about four times more LH than FSH (FSH:LH ratio about 0.25) (Fig. 1, Table Ia). Fractions I and II contained no detectable LH activity and only very weak FSH activity. Fraction III contained most $(58 \%)$ of the FSH activity ( $44 \mathrm{mg}$ pure $\mathrm{eFSH}$ ) and a minor part $(21 \%)$ of eLH that nevertheless exceeded the FSH fraction ( $59 \mathrm{mg}$ pure eLH), leading to an FSH:LH ratio of 0.75 . Fraction IV contained only a small amount of FSH and 25 -fold more eLH (FSH:LH ratio about 0.04).

Stepwise HIC. The two gonadotrophins were totally retained on the hydrophobic matrix, since no activity was found in the non-retained fraction I (Table Ib). Fraction II, eluted with $0.05 \mathrm{~mol}$ ammonium bicarbonate $\mathrm{l}^{-1}$, contained almost all FSH activity and only $6 \%$ of total LH giving a FSH:LH ratio of 4.4. Fraction III (eluted with $50 \%$ ethylene glycol) contained no measurable FSH activity and most of the LH activity. Fractions II and III were therefore enriched in FSH and LH activity, respectively, with either moderate or negligible crosscontamination. The purification procedure was then performed on a large scale. In preliminary experiments, we found that a $160 \mathrm{ml}$ phenyl Sepharose column was suitable for loading up to $2.5 \mathrm{~g}$ CEG without saturation. As in the small-scale procedure, Fraction I contained almost no FSH or LH (Table I). Fraction II contained almost all FSH and a small amount (16\%) of LH leading to an FSH:LH ratio of 4.2. Fraction III contained a small amount of FSH and most of the LH activity, leading to a low FSH:LH ratio $(0.06)$. These figures are very similar to those observed on a small scale and indicate that the easy and efficient separation of eFSH and eLH is feasible in large quantities allowing treatment of mares in vivo.

\section{In vivo treatment in mares}

Experiment 1. Evaluation of LH bioactivity in vivo in fraction III. Of 25 control mares, seven ovulated within $48 \mathrm{~h}$ after saline injection compared with 24 of 25 mares of the CEG group and 19 of 26 of the LH group (Fig. 2). Statistical comparison of intervals showed no difference between CEG and LH groups $(P>0.05)$ but a significant difference was found between both treated groups and the control group. Thus the biological activity of eLH in fraction III is preserved during HIC.

Experiment 2. Evaluation of FSH bioactivity in vivo in fraction II. The number of follicles that reached $30 \mathrm{~mm}$ in diameter was the same $(P>0.05)$ in CEG $(3.0 \pm 0.7)$ and in FSH $(3.0 \pm 0.5)$ groups, and both groups were different $(P<0.05)$ from the control group $(1.0 \pm 0.0)$ (Table 2). The interval from the first day of treatment to the day of ovulation induction (treatment duration) was not different $(P>0.05)$ in CEG $(5.9 \pm 0.8)$ or in FSH $(5.2 \pm 0.6)$ groups. The number of luteinized unruptured follicles was identical in the two treated groups $(0.7 \pm 0.5)$. Ovulation rates in treated groups were not 
Table 2. Effects of FSH activity of HIC fraction II in mares

\begin{tabular}{lccc}
\hline Parameter & $\begin{array}{c}\text { Control group } \\
(n=9)\end{array}$ & $\begin{array}{c}\text { CEG group } \\
(n=9)\end{array}$ & $\begin{array}{c}\text { FSH group } \\
(n=9)\end{array}$ \\
\hline $\begin{array}{c}\text { Ovulations per mare } \\
\text { Number of luteinized } \\
\text { unruptured follicles }\end{array}$ & $1.0 \pm 0.0$ & $2.2 \pm 0.6$ & $1.9 \pm 0.4$ \\
$\begin{array}{c}\text { Duration of treatment } \\
\text { (days) }\end{array}$ & 0 & $0.7 \pm 0.5$ & $0.7 \pm 0.5$ \\
$\begin{array}{c}\text { Number of follicles } \\
>30 \mathrm{~mm}\end{array}$ & $1.0 \pm 0.0$ & $3.0 \pm 0.7$ & $3.0 \pm 0.5$ \\
\hline
\end{tabular}

Mares were not treated (control group), injected daily with $25 \mathrm{mg}$ crude equine gonadotrophins (CEG group) or with fraction II from hydrophobic interaction chromatography (FSH group). Results are expressed as means $\pm \mathrm{SEM}$.

significantly different $(2.2 \pm 0.6$ in the CEG group and $1.9 \pm$ 0.4 in the FSH group) and were different from those of the control group in which ovulation rate was $1.0 \pm 0.0$ $(P<0.05)$. FSH bioactivity in vivo in fraction II from HIC was therefore preserved.

\section{Discussion}

Methods for obtaining highly purified eFSH and eLH have previously been reported by our group (Combarnous and Hengé, 1981; Guillou and Combarnous 1983) and by others (Licht et al., 1979; Bousfield and Ward, 1984). Equine LH and FSH activities cannot be separated by fractionated precipitation using ammonium sulfate or ethanol. Moreover, the two molecules have almost identical apparent molecular weights in size exclusion chromatography, and they exhibit multiple isoelectric points over the same range of $\mathrm{pH}$. Consequently, it has not yet been possible to separate FSH and LH activities without extensively purifying their individual isoforms (Guillou and Combarnous, 1983; Bousfield and Ward, 1984). Such methods are not feasible for large scale purification of these hormones for treatments in vivo.

Using a phenyl Sepharose matrix we have shown that the hydrophobic properties of the two molecules are sufficiently different so that an easy and efficient separation of the two activities, can be achieved.

This purification was first performed with a gradient of decreasing ionic strength together with an increasing gradient of ethylene glycol. The high concentration of ammonium sulfate in the starting buffer strengthens hydrophobic interactions, and in these conditions gonadotrophins are totally adsorbed to the matrix. They were subsequently and sequentially eluted from the column by decreasing the ammonium sulfate concentration and increasing the ethylene glycol concentration. This preliminary experiment clearly demonstrated that eLH and eFSH can be separated by this technique. Moreover, it directly led to a high yield of an LH fraction (IV) that exhibited $70 \%$ of the specific activity of highly purified eLH CY760.

On a large scale, it is much easier to operate reproducible stepwise elutions than gradients. We thus modified the initial technique for the production of large quantities of equine $\mathrm{LH}$ and FSH. The small scale purification of CEG $(80 \mathrm{mg}$ CEG on a $2.5 \mathrm{ml}$ column) indicated that there was no saturation of hydrophobic sites since no gonadotrophin activity was found in fraction I. The stepwise elution of eFSH and eLH was excellent since eFSH was obtained in fraction II with a good yield (94\%) and $\mathrm{LH}$ contamination was low. Elution of the eLH was obtained by lowering the polarity of the eluant with $50 \%$ ethylene glycol. The $\mathrm{LH}$ fraction obtained was as active as $0.7 \times$ eLH CY760 and it is therefore a very efficient first step for further purification. In the large scale preparation, fraction III had only a potency of $0.25 \times \mathrm{eLH}$ CY760. Nevertheless, it must be stressed that the initial LH content was lower in the CEG used in this experiment ( $\mathrm{FSH}: \mathrm{LH}=0.27$ ) than in the small scale purification ( $\mathrm{FSH}: \mathrm{LH}=0.7$ ).

Stepwise HIC is therefore very efficient for obtaining a good separation of FSH and LH from equine pituitary extract with recoveries of $90 \%$ for $\mathrm{eFSH}$ and $75 \%$ for eLH. This technique is easy to automate and permits the preparation of large amounts of gonadotrophins suitable for treatment of mares in vivo.

Experiments 1 and 2 were performed to evaluate activities present in the hormone preparations in vivo after HIC. Molecules might have been damaged during chromatography, especially carbohydrate moieties that are important for biological half-life and for signal transduction at the membrane level of target cells (Matteri and Papkoff, 1987, 1988).

In Expt 1, the doses of Fraction III and CEG injected into the mares corresponded to identical amounts of eLH as determined immunologically. As Fraction III and CEG gave identical responses in the induction of ovulation, it can be concluded that HIC does not alter the biological activity of eLH in vivo. Moreover, these results show that the presence of much larger amounts of FSH in CEG than in Fraction III has neither favourable nor unfavourable effects on $\mathrm{LH}$ action in the conditions used here. In Expt 2, the response to superovulation treatment (number of ovulations per mare) was the same with Fraction II as with CEG, when the two preparations were used at identical doses of immunoactive eFSH. Like eLH, eFSH is thus not altered by HIC and the higher content of LH in CEG compared with that in Fraction II has neither a positive nor negative effect on eFSH activity.

Since Fraction II and III are not more efficient than CEG for superovulation and ovulation induction, respectively, it might 
appear unnecessary to purify them. In fact, since the procedure has a very good yield, it produces almost twice as many hormone treatments, since each CEG dose gives one dose of FSH and one dose of $\mathrm{LH}$.

More importantly, in contrast to CEG, fractions II and III allow the optimum amount of each hormone and the control of the FSH:LH ratio throughout the superovulation protocols. The optimum number and size of preovulatory follicles at the time of induction of ovulation must be found to obtain a good synchronization of ovulations. The use of separate equine FSH and $\mathrm{LH}$ is required for this.

\section{References}

Bour B (1984) Stimulation de l'Inactivité Ovarienne Hivernale de la Ponette par des Gonadotropines Exogènes. Thèse, Institut National Agronomique Paris Grignon

Bousfield GR and Ward DN (1984) Purification of lutropin and follitropin in high yield from horse pituitary glands Journal of Biological Chemistry 259 1911-1921

Bousfield GR, Liu WK, Sugino H and Ward DN (1987) Structural studies on equine glycoprotein hormones: amino acid sequence of equine lutropin $\beta$-subunit Joumal of Biological Chemistry 262 8610-8620

Cahoreau C and Combarnous Y (1987) Comparison of two reference preparations for chorionic gonadotrophin in four in vivo and in vitro assays Journal of Reproduction and Fertility $79281-287$

Chupin D, Combarnous Y and Procureur R (1984) Different effect of LH on FSH-induced superovulation in two breeds of cattle Theriogenology 21 29-33
Combarnous $\mathrm{Y}$ and Hengé MH (1981) Equine follicle stimulating hormone: purification, acid dissociation and binding to equine testicular tissue Journal of Biological Chemistry $2569567-9572$

Duchamp G, Bour B, Combarnous $\mathrm{Y}$ and Palmer E (1987) Alternative solutions to hCG induction of ovulation in the mare Journal of Reproduction and Fertility Supplement 35 221-228

Guillou F and Combarnous Y (1983) Purification of equine gonadotrophins and comparative study of their acid dissociation and receptor-binding specificity Biochimica et Biophysica Acta 755 229-236

Lapin DR and Ginther OJ (1977) Induction of ovulation and multiple ovulations in seasonally anovulatory and ovulatory mares with an equine pituitary extract Joumal of Animal Science 44 834-842

Lecompte $F$ and Combarnous $Y$ (1992) Enzyme immunoassay (EIA) for equine chorionic gonadotropin/pregnant mare serum gonadotropin (eCG/PMSG) Journal of Immunoassay 13 483-493

Licht P, Gallo A, Aggarwal BB, Farmer SW, Castellino JB and Papkoff H (1979) Biological and binding activities of equine pituitary gonadotrophins and pregnant mare serum gonadotrophin Joumal of Endocrinology 83 311-322

Matteri RL and Papkoff H (1987) Characterization of equine luteinizing hormone by chromatofocussing Biology of Reproduction 36 261-269

Matteri RL and Papkoff H (1988) Microheterogeneity of equine follicle stimulating hormone Biology of Reproduction 38 324-331

Palmer E (1987) New results on follicular growth and ovulation in the mare. In Follicular Growth and Ovulation Rate in Farm Animals pp 237-255 Eds JF Roche and D O'Callaghan. Martinus Nijhoff Publishers, Dordrecht

Palmer E and Driancourt MA (1980) Use of ultrasonic echography in equine gynecology Theriogenology 13 203-216

Roser JF, Kiefer BL, Evans JW, Neely DP and Pachedco CA (1979) The development of antibodies to human chorionic gonadotrophin following its repeated injection in the cyclic mare Joumal of Reproduction and Fertility Supplement $\mathbf{2 7}$ 173-179

Woods GL and Ginther OJ (1983) Recent studies relating to the collection of multiple embryos in mares Theriogenoloy 19 101-108 